\title{
Nystatin Induced Changes in Growth, Viability and Amino acid Influx of Yeast Saccharomyces cerevisiae
}

\author{
Gopala Rao T.V.*, Sudip Kumar Sen, Amruta Samal, Soumya Satpathy \\ Department of Biotechnology, Gandhi Institute of Engineering and Technology, Gunupur-765022, Rayagada District, \\ Orissa, India, *Former address: School of Life Sciences, JNU-110067, India
}

\begin{abstract}
Polyene antibiotics are antifungal agents. They interact with cell membrane sterols and form pores in the membrane. All the cell constituents will leak through the pores and finally cell death occurs. Results of this paper have demonstrated that the specific phospholipids mutants of Saccharomyces cerevisiae which have been used to find out the the mechanism of action of antibiotic nystatin, by using the techniques of growth, viability and amino acid influx altered the sensitivity. The acquired resistance of phospholipids enriched cells as judged from (i) growth and viability could be dissociated (ii) the effect of antibiotics on the transport of amino acids was different from that of growth, viability and binding, which may due to the fact that membrane permeability changes could be dissociated. Further, the mutants, which accumulate PC (phosphatidyl choline) or PE (phosphatidyl ethanolamine) or PS (phospholipids serine) in the cell membrane, altered the sensitivity of antibiotic nystatin by non-specific binding of antibiotic to phospholipids. Further, these results would help for the pathogenesis control of Candida albicans, which is pathogenic yeast.
\end{abstract}

Key words- Saccharomyces cerevisiae, nystatin, polyene, growth, viability, phosphatidyle choline (PC) phospatidyle ethanolamine (PE), phospatidyl serine (PS)

\section{Introduction}

It has been generally recognized that cytotoxic effects of polyene antibiotics (e.g., nystatin, amphoterecin B) on fungi and animal cells are the result of induced membrane permeability changes [1,2]. However, several investigators have suggested that increased permeability can be separated from the more destructive (lytic) effects of the polyenes [2 - 5]. It is also reported that a polyene resistant mutant of Candida albicans showed that permeability alterations might not be a critical event in the lethal action of polyene antibiotics [6]. The dual effect of polyene amphotericin B was reported during the growth of C. albicans [7]. It was observed that amphotericin B inhibited phosphate uptake in $C$. albicans more strongly than its growth. This inhibitory effect was more in cells grown from young culture (culture grown for 2 hours) than the cells from old cultures (culture of 24 hours growth). It is also suggested that amphotericin B not only interact with sterol but also inhibit the synthesis of factor(s) responsible for its sensitivity [7-9]. There also reports to show that polyene antibiotics (at sub lethal concentrations) have a stimulatory effect on proliferation of animal cells and in the incorporation of labelled precursors in DNA and RNA [8-10]. Though it has been observed that polyenes may dissociate several physiological functions, effect cell growth, stimulate specific cell functions, the basis of these selective effects is not properly understood by many researchers [10-19]. It is suggested that polyene may not exclusively act by forming pores of varying sizes [19-26]. This is also confirmed earlier results of Medoff and his group also reported that where they had observed that the uptake of molecules larger than the pore diameter caused by polyene is also enhanced
[19-27]. Results of preceding publications have demonstrated that the specific enrichment of $S$. cerevisiae cells with either PC or PE or PS, leads to altered sensitivity of different polyenes [28]. It was shown that the uptake of amino acids which was used as an index of polyene action, was selectively affected by various antibiotics if membranes were enriched with different phospholipids. Results of this paper further demonstrate that altered nystatin sensitivity due to specific phospholipids enrichment could not only affect the influx of amino acids but also have a selective effect on cell growth and viability. Whether cell viability, growth and influx of amino acids versus polyene action could be correlated, are also discussed.

\section{Materials and Methods}

Materials for culture were obtained from Difco, USA. Rest all chemicals were obtained from Sigma Chemical Company, USA. Radio active amino acids were from Bhabha Atomic Research Centre, Bombay, India. Maxflow filters were obtained from Maxflow, Bombay. Few analytical organic solvents are from local companies (Rambaxy, Glaxo etc.,). The parental strain of Saccharomyces cerevisiae (ade $5 \alpha$ ) and mutant strain KA101 (a cho1, ino1, lys2, can1), requiring choline or ethanolamine for growth were obtained from Professor Susan A. Henry, Albert Einstein College of Medicine Bronx, New York, USA. Another strain of Saccharomyces cerevisiae (3059) was obtained from NCL, Pune, India. This 3059 strain was supplemented with hydroxylamine for the PS-enriched cells. Growth, medium preparation, transport assay, and lipid 
analysis were for both wild type and mutant were similar as of earlier publications [28, 29].

\section{Results \\ Effect of nystatin on cell growth}

Nystatin at various concentrations (0.01 to $10 \mu \mathrm{g} / \mathrm{ml}$ ) was added to exponentially growing cells of $S$. cerevisiae. There was no significant inhibition in growth rate if the concentration of nystatin used was below $0.1 \mu \mathrm{g} / \mathrm{ml}$, however, the inhibition as judged from the change in absorption, was variable and almost complete if the antibiotic used was in the range from 2 to 10 $\mu \mathrm{g} / \mathrm{ml}$ (Figs. 1 and 2). This effect of nystatin on cell growth was more or less similar in all types of cells (Figs. 1 and 2). However, upto $1 \mu \mathrm{g} / \mathrm{ml}$ of nystatin concentration, the growth of phospholipids-enriched cells offered some resistance (Figs. $1 \mathrm{~B}$ and $1 \mathrm{C} ; 2 \mathrm{~B}$ ). It was further observed that about 4 hours of incubation was necessary for the antibiotic to elicit its maximum effect on cell growth (Figs. 1 and 2). Therefore, exponential cells were further grown for 4 hours with nystatin to assess its effect on growth and high concentration $(10 \mu \mathrm{g} / \mathrm{ml})$ which caused complete cessation of cell growth were chosen for following experiments.

\section{Nystatin and cell viability \\ (a) PC- or PE-enriched cells}

At low concentratin of nystatin $(0.06 \mu \mathrm{g} / \mathrm{ml})$ where there was no detectable inhibition in cell growth, about $40 \%$ inhibition in cell viability was observed in ade $5 a$ cells (Fig. 3A). If the same concentration was used for PC- or PE-enriched cells, only 10 to $20 \%$ cell viability was affected (3A). However, at $10 \mu \mathrm{g} / \mathrm{ml}$ concentration, both the growth and cell viability were completely inhibited. It is clear from Fig.16A that the enrichment of cells with either PC- or PE, resulted in more survivors at different concentrations of polyene and that the effect of nystatin on growth and viability of $S$. cerevisiae cells could be dissociated at lower concentrations of the antibiotic.

\section{(b) PS-enriched cells}

Similar to PC- or PE-enriched cells, another batch of cells which were enriched in PS also exhibited resistance towards nystatin (Fig. 3B). There was no effect on cell viability at $0.06 \mu \mathrm{g} / \mathrm{ml}$ concentration of nystatin in PS-enriched cells while about $20 \%$ inhibition in cell survivors was observed in normal $S$. cerevisiae (3059) (Fig. $3 \mathrm{~B})$. It would appear that the enrichment of cells with either PC or PE or PS made them more resistant as far as their viability was concerned (Fig. 3). Although growth, as judged by change in absorbance, remained unaffected at low concentrations, viability was affected significantly at the same concentrations (Figs. 1-3).
Effect of Nystatin on Amino acids transport

As earlier reported that the addition of different polyenes $(10 \mu \mathrm{g} / \mathrm{ml})$ to PC- or PE- or PS-enriched cells during transport assay had a selective effect on the transport of various amino acids [20]. Except Glu, the transport of other amino acids became resistant to polyene action [20]. The effect of nystatin on amino acids uptake in this paper, is however, is somewhat different from previous results [20]. At a concentration of nystatin $(0.06 \mu \mathrm{g} / \mathrm{ml})$, where there was no effect on cell growth of ade $5 \alpha$, the transport of Phe and Gly was reduced, while Glu and Lys uptake remained un affected (Fig. 4A). However, 10 $\mu \mathrm{g} / \mathrm{ml}$ concentrations were able to inhibit the uptake of all the amino acids (Fig. 4A). When PC- or PE-enriched cells of KA101 (cho1) mutant strain were grown with different concentrations of nystatin $(0.06 \mu \mathrm{g} / \mathrm{ml}$ and $10 \mu \mathrm{g} / \mathrm{ml})$, significant differences were observed as compared to their counter part wild type strain (Figs. 4B and 4C). The lower concentration of antibiotic which inhibited the uptake of Gly, in ade $5 \alpha$, could not inhibit in PC- or PE-enriched cells. At $10 \mu \mathrm{g} / \mathrm{ml}$ concentrations, the uptake of Gly exhibited some resistance in $\mathrm{PE}$-enriched cells and complete resistance in $\mathrm{PC}$-enriched cells (Figs. 4B and $4 \mathrm{C})$. As compared to ade $5 \alpha$ and PC-enriched cells, the uptake of Glu became resistant in PEenriched cells (Fig. 4C). The uptake of Lys, however, was more sensitive to nystatin in PEenriched cells (Fig. 4C). The sensitivity of Phe uptake towards nystatin did not significantly change even after PC or PE enrichment of $S$. cerevisiae cells (Figs. 4B and 4C). PS enrichment of $S$. cerevisiae (3059) cells, on the other hand, had no effect on Glu, Lys, and to some extent Gly uptake with regard to their sensitivity towards nystatin action. The uptake of these amino acids except Phe, remained sensitive to nystatin even after PS enrichment (Fig. 5). The variation observed in amino acids transport, cell growth and viabililty with respect to nystatin action could be due to a change in polyene sensitivity which could vary as a function of cell growth. This fact was ascertained by the following experiments where nystatin sensitivity and binding were monitored during growth.

\section{Nystatin sensitivity versus cell growth}

The transport of Glu, Gly, Phe, and Lys in presence or absence of nystatin was followed in ade $5 \alpha$ at their different growth phases. The uptake of all these amino acids was high in exponentially growing cells, which dropped significantly near the stationary phase (Figs.6A and 7A). Nystatin when added to cells of different growth stages, exhibited a marked variable sensitivity. The transport of Glu, Phe, and Lys in ade $5 \alpha$ was very sensitive to nystatin (70 to $90 \%$ inhibition) during exponential growth which became completely resistant during the 
stationary phase (Figs. 6A and 7A). There was, however, no significant variation in Gly uptake versus nystatin action during entire growth period (Fig. 6A). In order to check if the phospholipids enrichment of $S$. cerevisiae cells would in any way affect the polyene sensitivity during growth, PC- or PE-enriched $S$. cerevisiae cells were subjected to nystatin. As compared to normal cells (Figs. 6A and 7A), the uptake of amino acids in PC- or PE-enriched KA101 (cho1) cells became insensitive to nystatin during the entire growth period (Figs. 6B and 6C; 7B and 7C). However, the maximum resistance towards nystatin was especially evident during exponential phase of growth (Figs. $6 \mathrm{~B}$ and $6 \mathrm{C}$; $7 \mathrm{~B}$ and $7 \mathrm{C}$ ). The general pattern of nystatin sensitivity of another strain $S$. cerevisiae (3059) was similar to ade $5 \alpha$ cells i.e. the cells were sensitive to nystatin during exponential phase (Fig. 8). The uptake of all amino acids remained sensitive to nystatin in early and mid-exponential phase and became resistant only at a later stage (Fig. 8). In contrast to normal cells (S. cerevisiae 3059), nystatin had a selective effect on amino acid uptake in PS-enriched cells. PS enrichment, on the other hand, did not have much effect of nystatin (Figs.9A and 9C). Thus, it would appear from these results that sensitivity towards nystatin during the growth of $S$. cerevisiae is also selectively influenced by phospholipids enrichment (Figs. 6 - 9).

\section{Lipid composition during growth}

The observed variation in nystatin sensitivity during various growth stages and the acquired resistance by phospholipids-enriched cells was further checked by estimating different lipid componenets during growth. As can be seen from Fig.10 that the individual phospholipids contents (PC or PE or PS+PI) did not vary significantly during different phases of growth. Same pattern was evident for the ergosterol content (Fig. 11). This would suggest that the phospholipid enichment (PC or PE or PS) which remained constant during entire growth (Fig. 10) was sufficient to provide resistance to cells towards nystatin (Figs. 6 - 9). There could be still some unknown factor(s) contributing towards variable polyene sensitivity.

\section{Nystatin Binding}

The observed variation in nystatin sensitivity could also be due to difference in the extent of its binding during growth or preincubation. The binding of nystain was more in PC- or PEenriched cells as compared to the wild type (ade $5 \alpha$ ) cells (Fig. 12A). Except after 8 hours of growth of PC-enriched cells, there was no significant change in the binding of nystatin during the growth of wild type and PC- or PEenriched cells (Fig. 12A). Expect after 8 hours of growth of PC-enriched cells, there was no significant change in the binding of nystatin during the growth of wild type and PC- or PEenriched cells (Fig. 12A). In S. cerevisiae (3059), initially there was no change in nystatin binding which increased upto 16 hours of the growth (Fig. 12 B). As compared to normal cells, nystatin binding increaed upto 12 hours of growth (Fig. 12 $B$ ). This would suggest that acquired resistance of phospholipids-enriched cells as judged from the amino acid transport is in no way correlated to the binding of nystatin since it is not substantially altered during the entire growth. In order to assess the differences observed in 10 minutes and 4 hours of incubation of nystatin, the total amount of bound nystatin was ascertained under both set of conditions. The binding of nystatin between 8.1 and $8.5 \mu \mathrm{g} / \mathrm{mg}$ protein in PC- or PE-enriched cells as compared to wild type where it was $1.9 \mu \mathrm{g} / \mathrm{mg}$ proteins (data not shown).

\section{Discussion}

Several investigators have been trying to explore the mechanism of action of polyene antibiotics [1]. Studies so far have proved that sterols are the prerequisite for interaction of sterol-polyene complexes which lead to the formation of pores in the membrane [3, 4]. Though these antibiotics affect the membrane affect the membrane permeability of ions and metabolites, the pore theory could not explain many of the physiological effects of polyene antibiotics on fungal, mammalian and bacterial cells [11]. Polyenes know to stimulate several functions of cholesterol (mammalian) and ergosterol (yeast) containing cells. It has been observed that polyenes stimulate DNA, RNA and protein synthesis of mammalian cells [16-18] and enhance the plating efficiency of C.albicans yeast cells [2-6]. Another interesting evidence for polyene stimulation of several physiological functions is their effect on no sterol membrane components. Another report of Medoff and his group [23, 24] has shown that polyene at higher concentration were non-toxic to bacteria and were provoking an increase in their colony forming ability. Such non-sterol-polyene interactions and their colony forming ability. Such non-sterol-polyene interations and their stimulatory effects on lymphocytes have also been reported [18]. Based on these experimental data it has been concluded that polyenes can stimulate several physiological functions of both sterol and non-sterol containing cells. It has also been assumed that the stimulatory mechanism may be different in sterol containing cell from that of bacteria where there is no sterol indicating that other membrane components also play an important role in polyene action. In addition, several investigators have reported a dissociation between membrane permeability and other physiological functions (growth, viability, 
permeability, hemolysis etc.,). The polyenes which do not induce potassium leakage from viable cells can potentiate the growth and anticellular action of other agents [11, 12]. In 1984 Brajtburg and his group have reported that the dissociation of different functions is specific. They have reported that increase in potassium permeability (efflux) is associated with an increase in uridine incorporation into RNA but not themidine incorporation into DNA [18]. Results of this paper demonstrated that growth of ade $5 a$ cells was not significantly inhibited at lower concentratin of nystatin but its viability was affected significantly (Figs. 14-16). It seems that a slight reduction in growth is sufficient to cause the reduction in cell viability. At higher concentrations of nystatin, however, the maximum inhibition of growth is associated with the decrease in viability. The percentage reduction in cell survivors (viability) versus cell growth was different in phospholipid-enriched cells. Similar concentration of nystatin was less effective in suppressing cell growth and viability of phospholipid-enriched cells. The effect on both growth and viability indicated that phospholipid-enriched cells probably acquired resistance towards nystatin. It is also apparent that at lower concentration of nystatin. It is also apparent that at lower concentration of nystatin, its effect on cell viability and growth can be dissociated, however, at higher concentration both functions appear to be correlated. The effect of nystatin on the transport of amino acids was different from that on growth and viability. This may be due to the fact that membrane permeability changes could be dissociated with other physiological functions [17, 18]. At lower concentration of nystatin, where cell viability is reduced, the influx of only certain amino acids transport is quite selective. The uptake of amino acids transport is quite selective. The uptake of amino acids in PC- or PE- or PS-enriched cells in the presence of the antibiotic was different from the wild type. The resistance acquired as judged by the influx of amino acid also suggested selectivity towards nystatin and its concentration. The resistance acquired by PC- or PE- or PSenriched cells was observed as earlier reported $[28,29]$. The difference between the resistance accorded by the amino acid influx reported as earlier [28, 29] and now may be due to the differences in the method of incubation of polyene action. When cells were preincubated with $10 \mu \mathrm{g} / \mathrm{ml}$ antibiotics for 10 minutes, and allowed to be present during the transport assays, maximum resistance was observed as juddged by the amino acid influx which was not evident if the cells were grown in $10 \mu \mathrm{g} / \mathrm{ml}$ for 4 hours. That the cells which were grown in 10 $\mu \mathrm{g} / \mathrm{ml}$ of nystatin were more sensitive than those exposed to 10 minutes was further supported by the binding results. A 2 - to 3 -fold increase in nystatin binding was observed in 4 hours grown cells as compared to those cells which were incubated with nystatin for 10 minutes duration. Several investigators have observed that the binding of polyene remain constant at higher concentration after 1 to 2 hours of incubation. This could be due to the fact that the plasma membrane surface area of yeast cells corresponding to $1 \mathrm{mg}$ dry solid is approximately $2.5 \times 1015 \mathrm{~nm}^{2}$ which will be saturated with nystatin molecules $\left(3 \mathrm{~nm}^{2}\right)$ with in 1-2 hours of incubation [13-16]. It may also be possible that the time taken for the antibiotic to penetrate the cell wall and to affect the cell membra ${ }^{2}$ ne may not correlate with the 10 minutes incubation, Thus, in 10 minutes maximum antibiotic is bound to cell wall rather than to the plasma membrane. Therefore, only a minimum amount of polyene would interact with membrane sterols and other components if cells incubated with the drug for shorter time. It is quite probable that polyene could be less lethal to cells exposed to shorter duration. It is apparent that the polyene sensitivity could not be explained only on the basis of sterol contents. Polyenes effect on specific stimulation of viability, growth, transport proteins, and their dissociation and association with each other under various conditions suggest that polyene antibiotics mechanism of action is very complex. It seems that each and every membrane component may play a significant role towards polyene action.

\section{References}

[1] Bossche V,H. et. al. (1994) J. Med.Vet. Mycol. 32:189-202.

[2] Cybulska B., Mazerski J., Borowski E. and Bobo M.G. (1984) Biochem. Pharmacol. 33:41-46.

[3] Chen W.C., Chou D.L. and Feingold D.S. (1978) Antimicro. Agents Chemother. 13: 914-917.

[4] Fisher P.B., Bryson V. and Schaffner C. (1978) J. Cell Physiol. 97: 345-352.

[5] Brajtburg J., Medoff G., Kobayashi G.S. Elberg S. and Feingold C. (1980a). Antimicro. Agents Chemother. 18: 586592.

[6] Brahtburg J., Medoff G., Kobayashi G.S. and Elberg S. (1980b). Antimicro. Agents Chemother. 18: 593-597.

[7] Hsu Chen C.C. and Feingold D.S. (1973). Antimicrob. Agents Chemother. 4:309319.

[8] Berdicevsky I. and Grossowicz N. (1977) J. Gen. Microbial. 102: 299-304.

[9] Kotler-Brajtburg J., Medoff G., Schlessinger D. and Kobayashi G.S. (1977) Antimicrob. Agents Chemother. 11: 803808.

[10] Kitagawa T. and Andoh T. (1978) Exp. Cell Res. $115: 37-46$ 
[11] Akiyama S., Hidaka K., Komiyamma S. and Kuwano M. (1979) Cancer Res.39:51505154.

[12] Akiyama S., Tubuk T., Kan eko M., Komiyamma S. and Kuwano M. (1980) Anti Micro.agents. Chemother. 18:226230.

[13] Beezer A.E.and Chowdary B.Z.(1980) Microbios.28:107-121

[14] Beezer A.E.and Sharma P.B.(1981a) Microbios.30:121-126

[15] Beezer.A.E.and Sharma P.B.(1981b) Microbios.31:7-16

[16] Beezer A.E.andSharma P.B.(1981c) Microbios.31:7182

[17] Brajtburg J., Elberg S., Medoff J., Kobayashi G.S., Schlessinger D. and Medoff G. (1984) Agents Chemother. 26, 892897

[18] Brajtburg J.,Elberg S.,Medoff G. and Kobayashi G.S. (1981) Antimicrob. Agents Chemother.19:199-200

[19] Kruijff B.D. and Demel R.A. (1974) Biochim.Biophys.Acta339:57-70.

[20] Malewicz ,D., Jenkin H.M. and Borowski E.(1981) Agents Chemother.19:238247.

[21] Mechlinski W., Schaffner C.P., Ganis P. and Avitabile G. (1970)Tetrahedron Lett.44:3873-3876.

[22] Mechlinski W.,Schaffner C.P.(1974) J.Chromtogr.99:619-633.

[23] Medoff G.,Kobayashi G.S., Kwan C.N., Schlessinger D. and Venkov P. (1972) Proc. Natl. Acad. Sci. USA. 69:196-199.

[24] Medoff G., Kwan C.N., Schlessinger D. and Kobayashi G.S. (1973) Antimicrob. Agents Chemother. 3:441-443.

[25] Medoff G., Valeriole F., Lynchi R.G., Schlessinger D. and Kobayashi G.S. (1974) Cancer Res.34:974-979.

[26] Medoff G., Brajtburg J., Kobayashi G.S. and Bolard J. (1983) Toxicol. 23:303-330.

[27] Malewicz D., Jenkin H.M. and Borowski E. (1980)

Antimicrob.Agents Chemother.17:699-706.

[28] Rao T.V.G., Trivedi A. Prasad R. (1985) Can. J. Microbiol. 31:322-326.

[29] Rao T.V.G., Das S. and Prasad R. (1985) Microbios 42:145-153. 


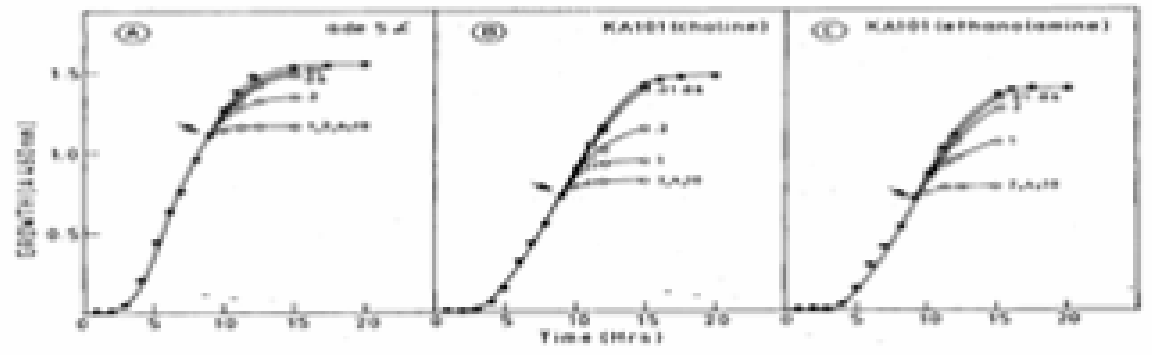

Fig. 1- Effect of different concentrations of nystatin on growth of Saccharomyces cerevisiae (ade $5 a$ and KA101) cells. Cells were grown at $300 \mathrm{C}$ upto mid exponential phase and different concentrations of nystatin $(0.01$ to $10 \mu \mathrm{g} / \mathrm{ml}$ ) were added.Growth was assessed by measuring absorbance at $460 \mathrm{~nm}$.

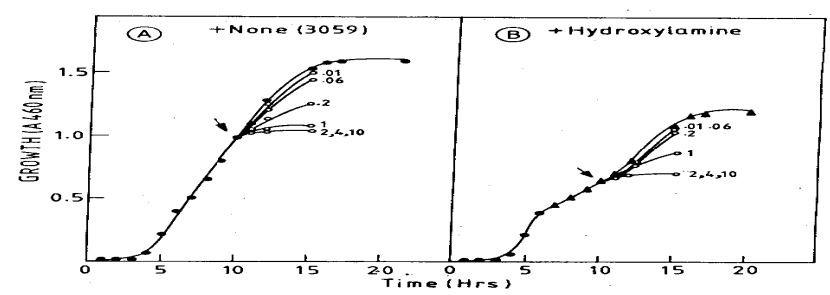

Fig. 2- Effect of different concentrations of nystatin on growth of Saccharomyces cerevisiae (3059) cells. Ce11 were grown at $30^{\circ} \mathrm{C}$ upto mid exponential phase and different concentrations of nystatin $(0.01$ to $10 \mu \mathrm{g} / \mathrm{ml}$ ) were added. Growth was assessed by measuring absorbance at $460 \mathrm{~nm}$,

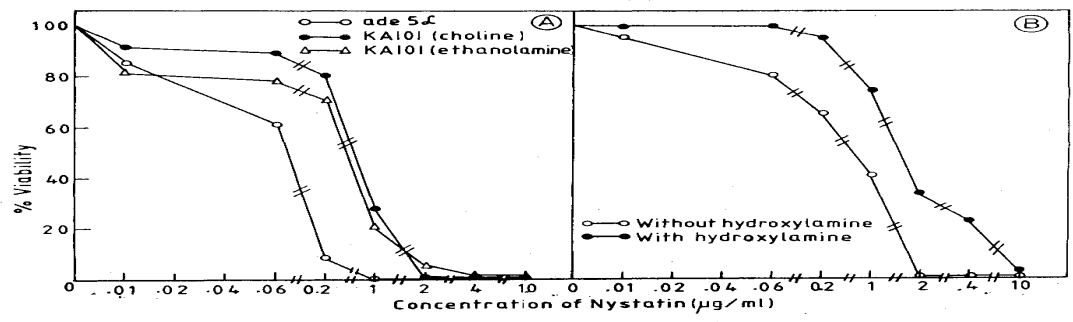

Fig. 3- Effect of different concentrations of nystatin on the normal, PC-, PE-, and PS-enriched cells viability. Exponential phase cells were incubated with different concentrations of nystatin $(0.01$ to $10 \mu \mathrm{g} / \mathrm{ml})$ at $300 \mathrm{c}$ for 4 hours. Cell viability was deter mined as described in earlier 


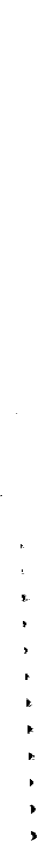

(B) (C)

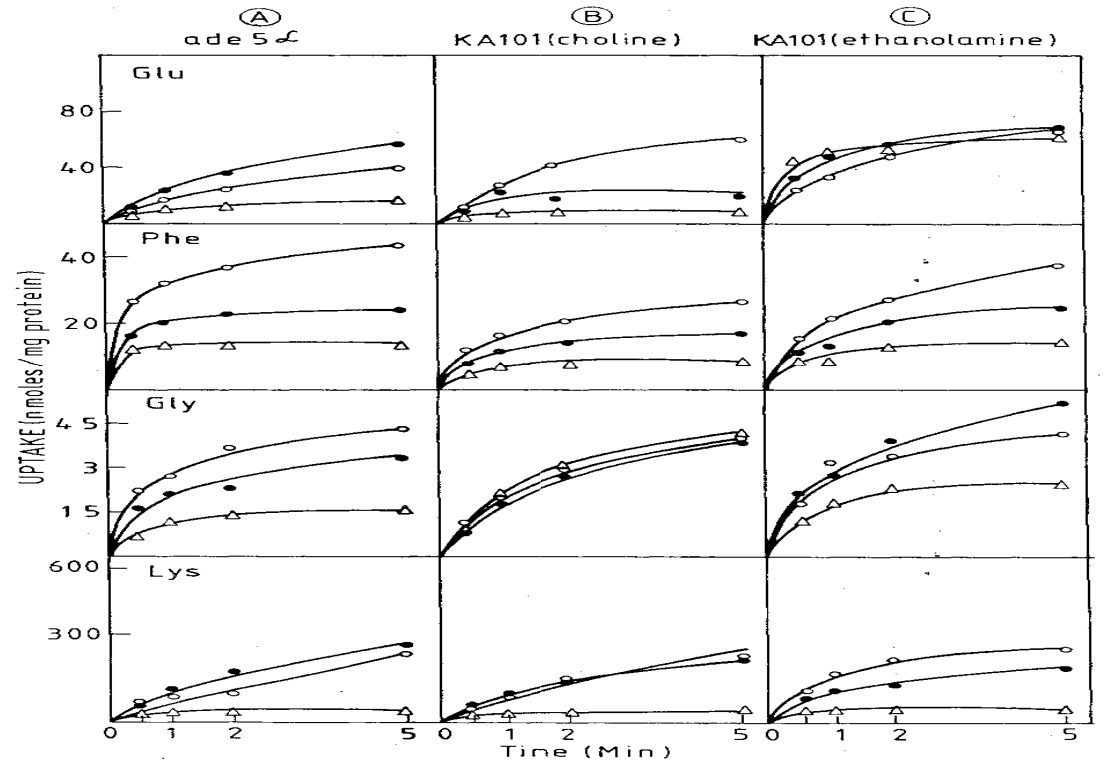

Fig. 4- Uptake of Glu, Phe, Gly, and Lys in (A) ade 5a, (B) KA1O1 (choline),and (C) KA1O1 (ethanolamine) cells. Exponential phase cells were further grown in presence of different concentrations of nystatin $(0.06$ and $10 \mu \mathrm{g} / \mathrm{ml})$ at $30^{\circ} \mathrm{C}$ for $4 \mathrm{hrs}$.After $4 \mathrm{hrs}$.growth antibiotic was removed by centrifugation and uptake of different amino acids was performed as described in'Materials and Methods'. Uptake in normal grown cells. Uptake in $.06 \mu \mathrm{g} / \mathrm{ml}$ nystatin grown cells. Uptake in $10 \mu \mathrm{g} / \mathrm{ml}$ nystatin grown cells

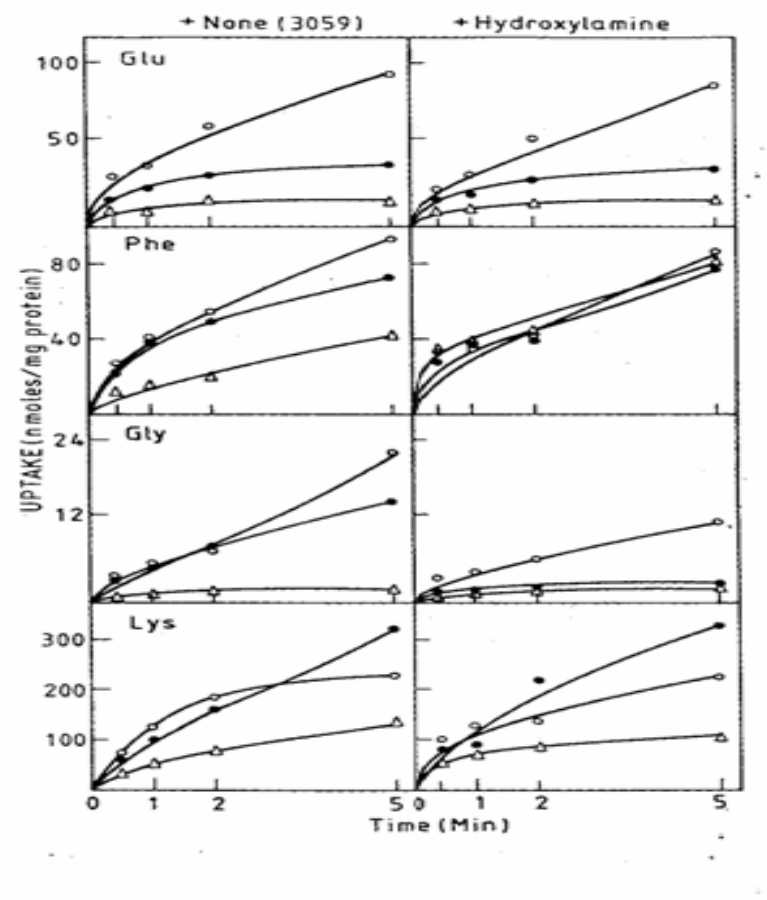

Fig. 5- Uptake of Glu, Phe, Gly, and Lys in normal and hydroxylarnine added Saccharomyces cerevisiae 3059 cells. Exponential phase cells were further grown in presence of different concentrations of nystatin $(0.06$ and $10 \mu \mathrm{g} / \mathrm{ml})$ at $30^{\circ} \mathrm{C}$ for $4 \mathrm{hrs}$. After $4 \mathrm{hrs}$. growth antibiotic was removed by cen-trifugation and uptake of different amino acids was performed as described in earlier.

Uptake in normal grown cell. Uptake in $0.06 \mu \mathrm{g} / \mathrm{ml}$ nystatin grown cells. Uptake in $10 \mu \mathrm{g} / \mathrm{ml}$ nystatin grown cells 


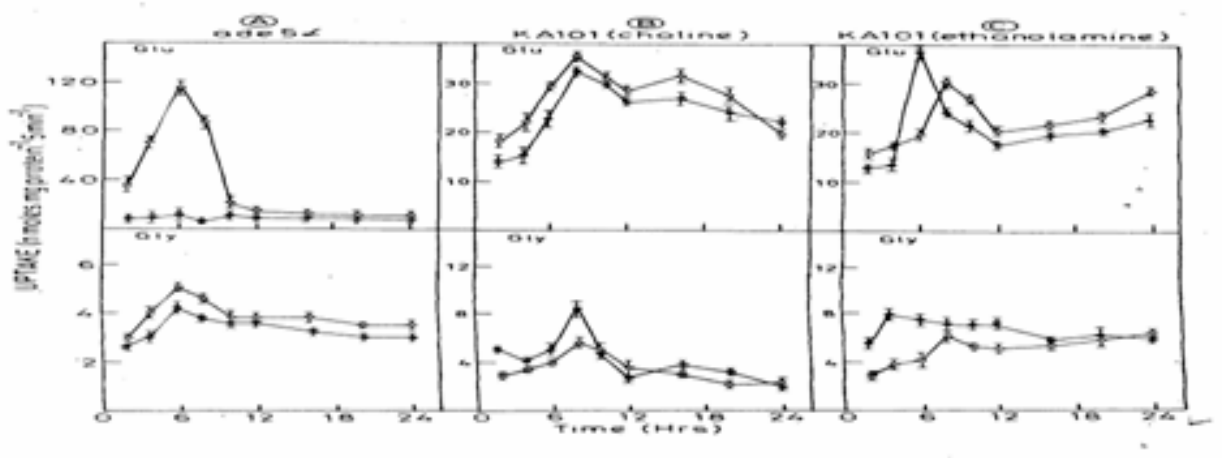

Fig. 6- preincubated with nystatin ( $10 \mu \mathrm{g} / \mathrm{ml}$ concentration) for $10 \mathrm{~min}$ before performing transport assay. Uptake in the absence of nystatin Uptake in the presence of nystatin $(10 \mu \mathrm{g} / \mathrm{ml})$.

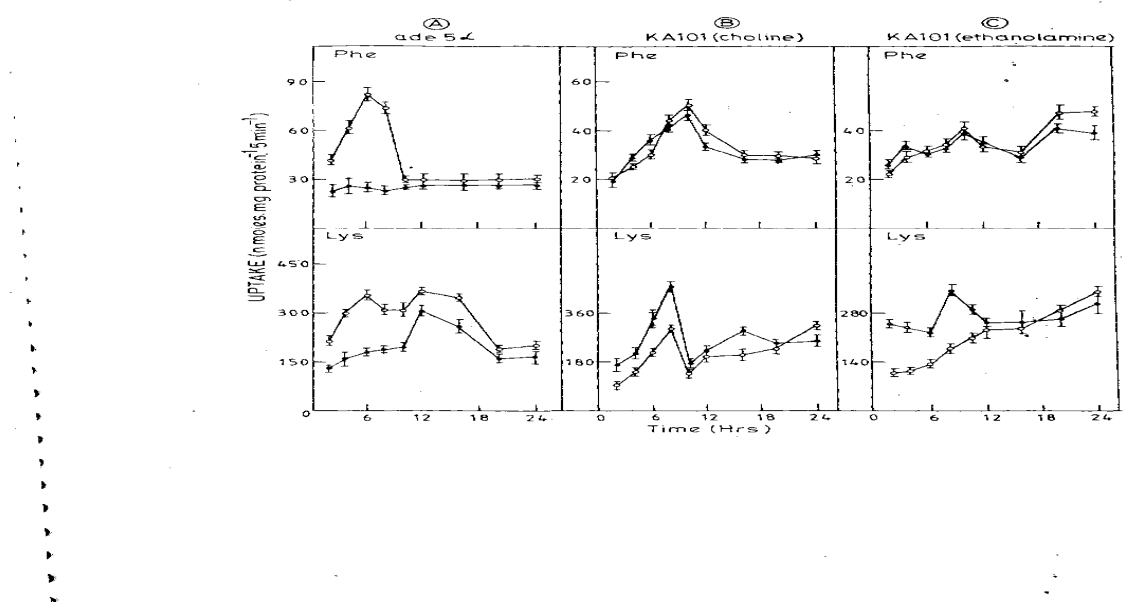

Fig. 7- Effect of nystatin on the uptake of Phe andLys during different growth stages of (A) ade $5 a,(B)$ KA101(choline) and(C) KA101 (ethanolarnine) cells. Uptake in the absence of nystatin. Uptake in the presence of nystatin $(10 \mu \mathrm{g} / \mathrm{ml})$. 


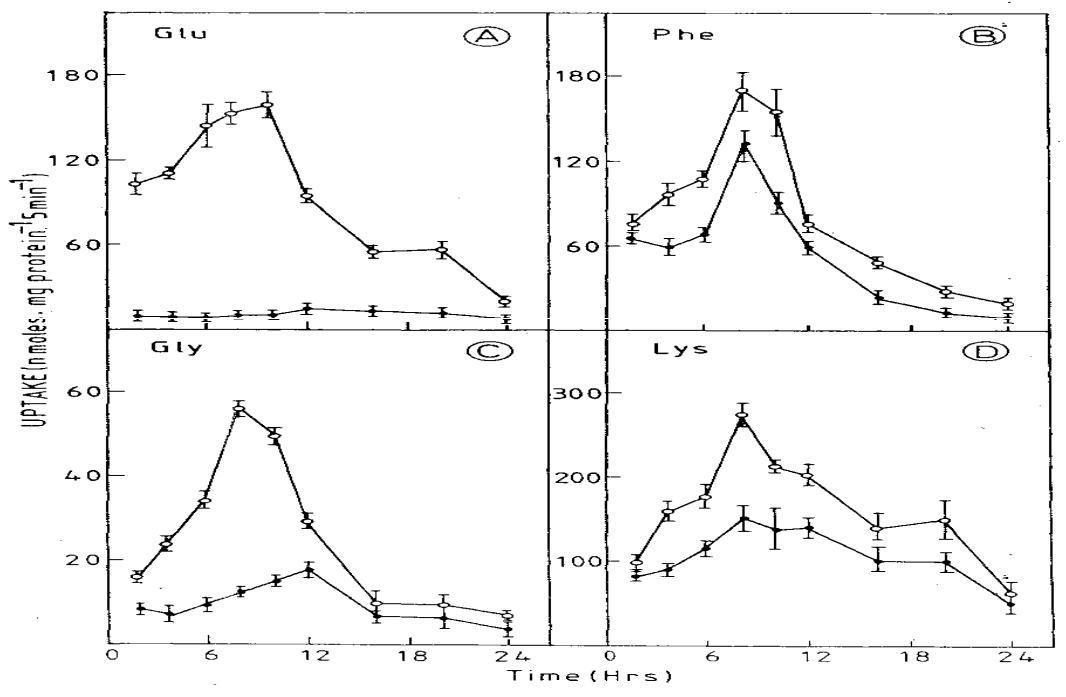

Fig. 8- Effect of nystatin on the uptake of Glu, Phe, Gly, and Lys during different growth stages of Sacoharomyces cerevisiae (3059). Uptake in the absence of nystatin. Uptake in the presence of nystatin $(10 \mu \mathrm{g} / \mathrm{ml})$.

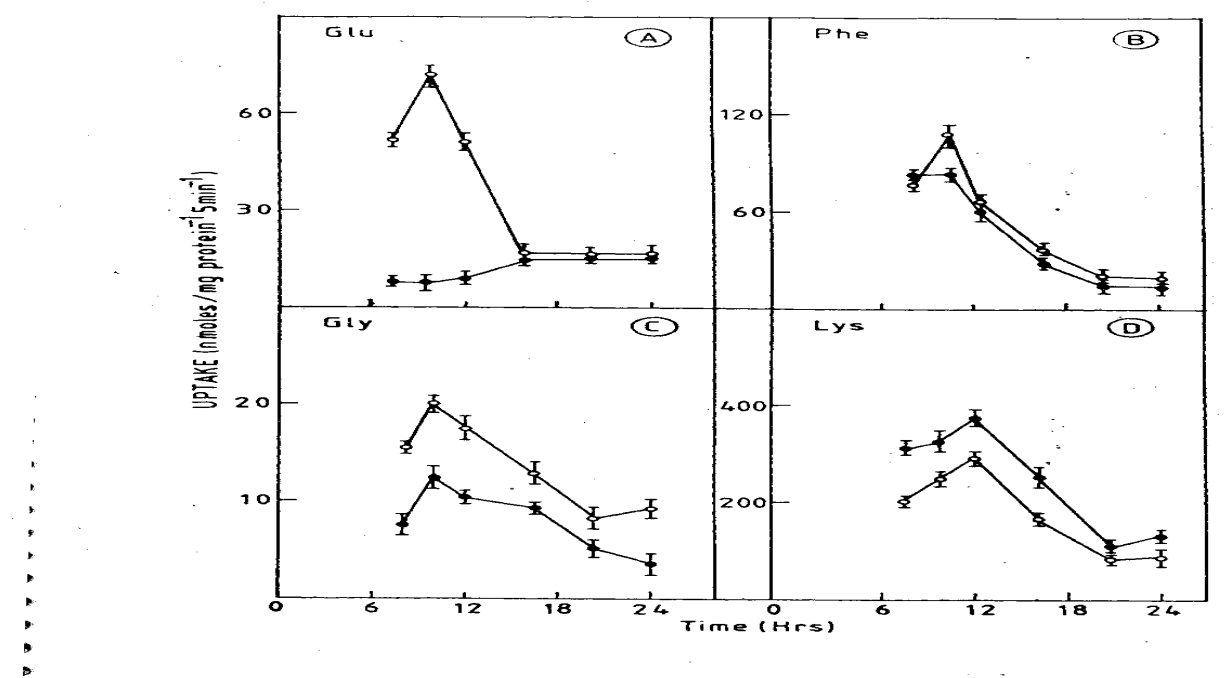

Fig. 9- Effect of nystatin on the uptake of Glu,Phe.Gly andLys during different growth stages of PS enriched Saccharomyces cerevisiae(3059). Uptake in the absence of nystatin. Uptake in the presence of nystatin $(10 \mu \mathrm{g} / \mathrm{ml})$. 


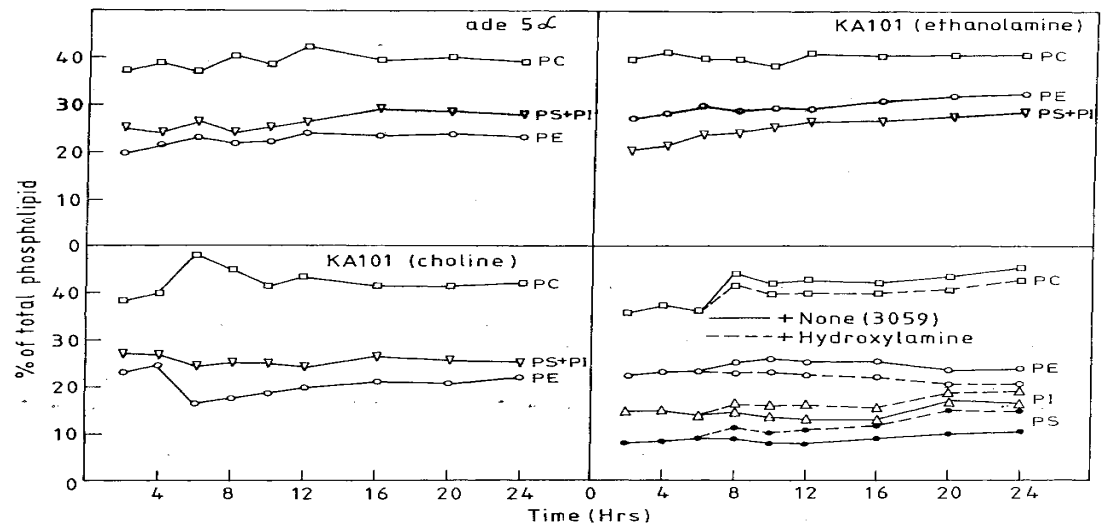

Fig. 10- Phospholipid composition during different growth stages of Saccharomyces cerevisiae 5a,KA101, and 3059). Different phospholipids were separated and estimated as described In earlier.

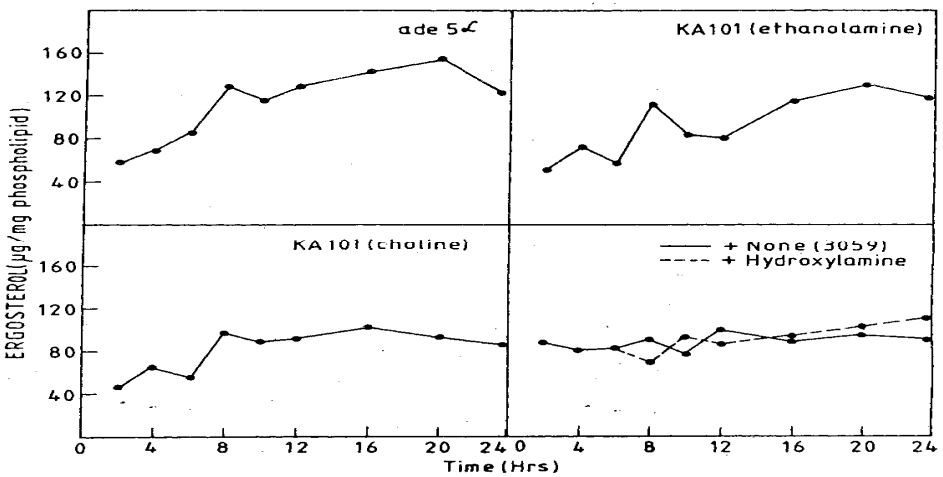

Fig. 11- Ergosterol content during different growth stages of Saceharornyces cerevisiae (ade 5a, $\mathrm{KA1O1}$, and 3059). Ergosterol content was determined as described in earlier

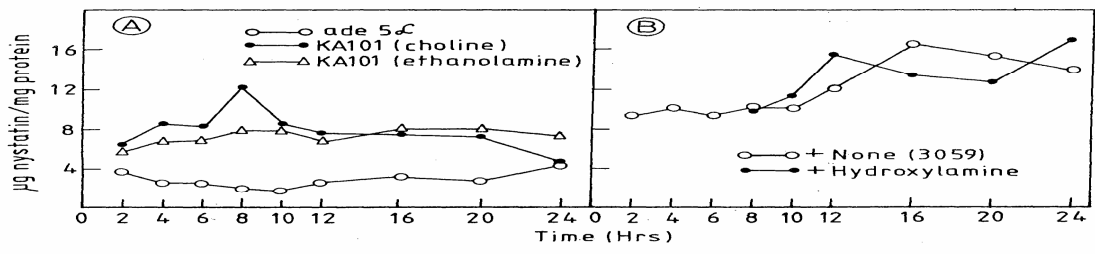

Fig. 12- Binding of nystatin during different growth stages of Saceharomyces cerevisiae (ade 5a, KA101, and 3059). Cells were harvested at indicated stages of growth and incubated with $10 \mu \mathrm{g} / \mathrm{ml}$ nystatin.After 10 minutes of incubation,cells were centrifuged and UV absorption of nystatin in the supernatant was measured as described in earlier. 